
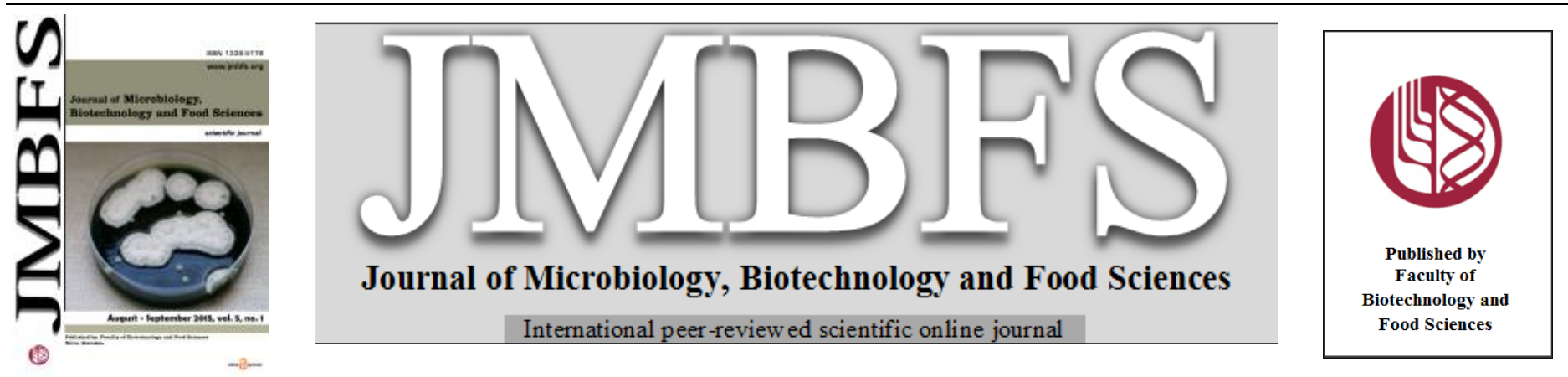

\title{
THE EFFECT OF INDIVIDUAL COMPONENTS OF TOTAL MIXED RATION (TMR) ON PRECISION DOSING TO MIXER FEEDER WAGONS
}

\author{
Marie Šistkova ${ }^{1}$, Martin Pšenka* ${ }^{2}$, Vladimír Kaplan ${ }^{3}$, Jiři Potěšil ${ }^{4}$, Jiři Černín ${ }^{5}$
}

\author{
$\operatorname{Address}(e s):$ \\ Budejovice, Czech Republic, +420 387772926. \\ ${ }^{2}$ Slovak University of Agriculture in Nitra, Faculty of Engineering, Tr. A. Hlinku 2, 94976 Nitra, Slovakia, +421 376415677. \\ ${ }^{3}$ ZEAS, a.s. Pod Kunětickou horou, Staré Hradiště 490, 53352 Staré Hradiště, Czech Republic. \\ ${ }^{4}$ Agricultural Society Ostřetín, a.s., Ostřetín 273, 53401 Holice, Czech Republic. \\ ${ }^{5}$ Cernin s.r.o., Kružberk 38,747 86 Kružberk, Czech Republic.
}

${ }^{1}$ University of South Bohemia in Budweis, Faculty of Agriculture, Department of Agricultural, Transport and Handling Machinery, Studentska 13, 37005 Ceske

*Corresponding author: psenka.martin@gmail.com

doi: 10.15414/jmbfs.2015.5.1.60-63

\section{ARTICLE INFO}

Received 21. 5. 2015

Revised 17. 6. 2015

Accepted 1. 7. 2015

Published 1. 8. 2015

Regular article open 2 access

\begin{abstract}
At present, in large-scale breeding of cattle occurs no longer feeding with one forage feeding system. The cattle are fed with feeding technique called total mixed ration (TMR). In TMR are all the feeds (bulky and grainy) and mineral and vitamin supplements mixed into a homogenous mixture. For the mixing of individual components of TMR are used mixer feeder wagons, that can be used not only for mixing of feeding ration, but also for discharging the fodder from wagon to fodder table in barn. Very important is the accuracy of dosing the individual components into the ration. The aim is to ascertain the precision during loading of individual components into the mixer feeder wagons. When loading, the dosing accuracy is influenced by many factors. Most important ones are used technique (loaders, hoppers, chopping devices, silage block cutters), human factor (expertise and responsibility of the operator), physical properties of the individual components (size, shape and density) and the loaded weight of components. On a cattle-breeding farms (600 pcs), was performed accuracy monitoring of loading selected individual components of TMR, common to several kinds of recipes, such as CCM (corn cob mix), haylage, silage and straw into mixer feeder wagons Storti Labrador 120 and Cernin C11. These mixer feeder wagons are equipped with electronic tensometric scales and responder for transfer of data to PC. From the PC software was, by the individual components, investigated programed weight $(\mathrm{kg})$, actually loaded weight $(\mathrm{kg})$ and deviations between programed and actually loaded weight (\%).
\end{abstract}

Keywords: Mixer feeder wagon, total mixed ration, fodder

\section{INTRODUCTION}

Nutrition of cattle affects not only the production intensity, but also the quality of meat and milk. It is decisive external factor of production of safe, high-quality biological products intended for direct human nutrition, or used for production of food (Suchý et al., 2011).

For dairy cattle with high milk yield is important to guarantee maximum dry matter intake and balanced concentraton of nutrients in dry matter (Sindhöj, Rodhe, 2013).

In the nutrition of dairy cows, is currently mostly used total (complex) mixed ration (TMR), which improves the digestibility of ration (Amaral-Phillips, Bicudo, Turner, 2002, 2010). Total mixed rations are designed as a homogeneous mixture to help minimize the selective consumption of individual feed components by dairy cattle (Coppock $\boldsymbol{e t}$ al., 1981). When cows are provided a total mixed ration (TMR) most feeding occurs soon after the delivery of fresh food (DeVries and von Keyserlingk, 2005), likely reflecting the higher nutritional value of the fresh TMR (DeVries et al., 2005 and Hosseinkhani et al., 2008). TMR improves digestibility, palatability and labor-saving (Alen, 2009). Especially in intensive breeding systems, the emphasis is placed on feeding with TMR (Javorek, 2011). While receiving the TMR, dairy cows are receiving destined ratio of the core and coarse fodder, including macro and micro elements and vitamins mixed together. TMR optimally solves the physiological needs of a cow and rumen microflora (Amaral-Phillips, Bicudo, Turner, 2010). These benefits of TMR are applied only when the feed ration (given to animals) is as close as possible to calculated ratio. Also when all ration components were sufficiently homogeneous stirred therein by mixer feeder wagon, according to Amaral-Phillips, Bicudo, Turner (2010) at most mixer feeder wagons is sufficient to stir 3-6 minutes, and the whole TMR was also consistent (must have a certain appropriate humidity). Failure to follow these principles has significant effect on the performance and health of animals.

In practice, there are basically three types of TMR. The first type is feed ration theoretical - calculated by optimization program and quantified sometimes up to two decimal places. The second type is a TMR that leaves the mixer feeder wagon and is discharged into fodder table in barn to animals (depending on the accuracy of loading and homogeneity - mixing of individual components). The third TMR type is the dose that cows actually receives. There are many factors influencing the difference between the theoretical and actual accepted ration. According to Stokes (1997), not only the accuracy of loading, but also the type of mixer feeder wagon, loading sequence of the individual components of TMR, mixing time and sorting of animals.

Mixer feeder wagons successfully proved itself in preparing TMR for dairy cows (Vegricht J. et al., 2008), and in intensive breeding systems are used primarily (Javorek, 2013). According to the results of research in 2011 (in $250 \mathrm{Czech}$ farms), feeding cows were provided in $87 \%$ of stables using different types of mixer feeder wagons (MFW), or feeder wagons with floor conveyor (Vegricht, Šmon, 2012). The feeder mixing wagon definitely include built-in tensometric scale that allows the preparation of rations exactly according to prescribed formulas based on exact recipe and also allows control of the amount of fodder given to animals (Vegricht J. et al., 2008).

An obvious modern equipment of MFW is a tensometric weight with program for management of ration preparing. Feed management software provides the tools that allow better control of whole farm nutrient balance if used properly (James, Cox, 2008). Thank to weighting system, components can be relatively accurately dosed. The MFW's include different types of memory storage devices. This 
allows storing of any of these recipes (Javorek, 2013), particularly up to 100 recipes and 24 components (Vegricht, Šimon, 2012), and currently even more. This is a data transmission system (common wireless transmission or transfer via USB), in which it is possible to save all the work cycles (Vegricht, Šimon, 2012). The software allows the compilation of individual recipes of loadings on PC and data transfer between PC and the weight of the wagon for the control of feeding, control of load and unload times and control of deviations between actually loaded amount and programmed amount of components.

Separating, loading and filling of individual components of TMR into carriage body of feeder mixer wagon can be made by self-loading equipment (eg. rotary cutter with cutter knives), which is an integral part of the wagon, or for filling and loading is used stand-alone device (eg. silage block cutter)

In terms of monitoring the process of filling and observance of the prescribed formulas are more preferred weighing systems showing laden mass of fodder continuously, when the weighing device monitors the course of loading and timely signals at the prescribed weight (eg. first signal upon completion of $80 \%$ of dose and second after reaching $100 \%$ ). For example, according to Vegricht and Šimon (2012) is developed a sensor that measures the humidity of fodder sample and in case that its dry matter differs from dry matter used in calculating of ration, the software re-calculates and adjusts the needed amount of loaded fodder.

\section{MATERIAL AND METHODS}

On two farms for cattle (about 600 pieces) was performed monitoring of the accuracy of the loading of individual components of TMR, common to both farms and more kinds of recipes. The aim was to determine the precision when loading the components of TMR into mixer feeder wagon depending on their individual types and ways of management.

Monitoring was performed on trailed horizontal mixer feeder wagon Labrado 120 (year of manufacture 2003, volume of carriage body $12 \mathrm{~m}^{3}$ ) with one central mixing device (screw) with self-loading cutter mounted on a hydraulically positioned arm with loading the carriage body through the rear face. The second wagon was trailed vertical MFW Cernin C 11 (year of manufacture 2011, volume of carriage body $11 \mathrm{~m}^{3}$ ) with mixing van equipped with a single mixing device (screw).

Both mixer feeder wagons were equipped with three point electronic tensometric scales and a responder for data transfer to PC (Figure 1).

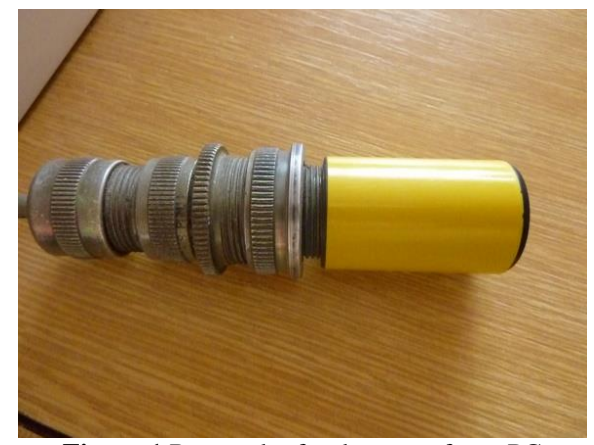

Figure 1 Responder for data transfer to PC

\section{Mixer feeder wagon filling}

Labrador 120 - loading of individual components was performed by loading cutter, which is an integral part of the vehicle.

Cernin C 11 - loading of individual components was performed by loader JCB 524-50 with the loader bucket.

Types of loaded components were common to both wagons: CCM (Corn cob mix), haylage, silage and straw.

The order of loaded individual components was determined by their order in the recipe (can be different for each recipe) has not been monitored.

From PC software programs history, the difference between the programmed weight and actually loaded weight has been investigated (so-called operator error indicated in \%).

\section{RESULTS AND DISCUSSION}

The resulting values are shown graphically for an overview. Figures 2 and 3 are showing the numbers of precision, of over-limit and under-limit loadings for both types of loadings (Figure 2 Labrador 120 - rotary loading cutter, Figure 3 Cernin C11 - loader JCB 524-50) of all common components. When loading with rotary loading cutter is the number of over-limit loadings higher than $4.98 \%$ than under-limit loadings. When loading with loader is number of over-limit loading higher about $87.15 \%$. Number of precise loadings with rotary loading cutter is higher about $7.25 \%$ than in loading with loader.

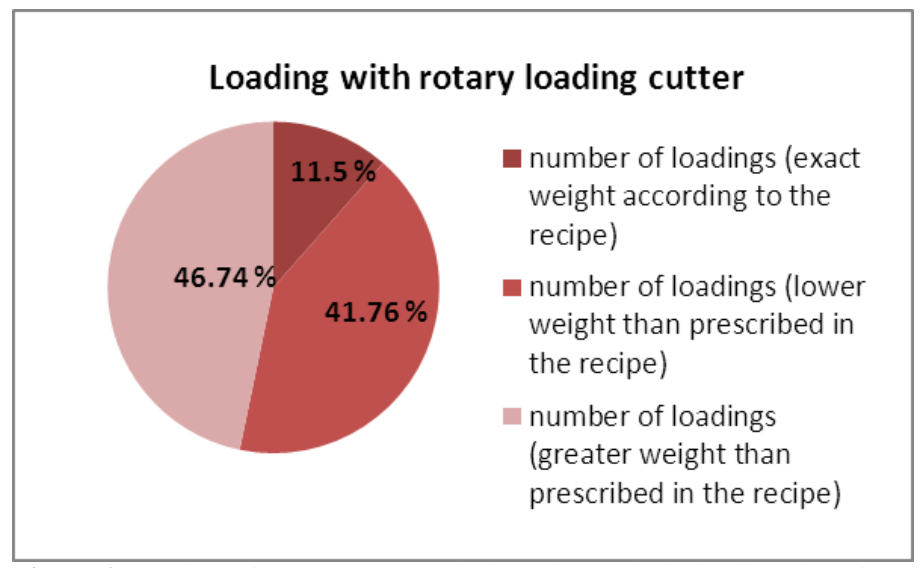

Figure 2 Number of accurate, under-limit and over-limit loadings into feede mixer wagon Labrador 120

\section{Loading with loader JCB 524-5}

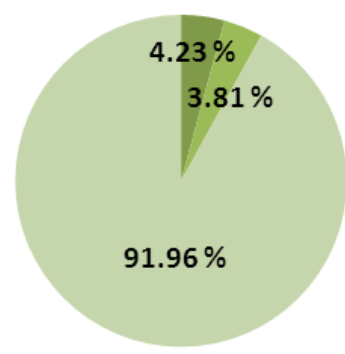

number of loadings (exact weight according to the recipe)

number of loadings (lower weight than prescribed in the recipe)

number of loadings (greater weight than prescribed in the recipe)

Figure 3 Number of accurate, under-limit and over-limit loadings into feeder mixer wagon Cernin C11

The figures $4-11$ are showing the numbers of exact, of over-limit and underlimit loadings of each individual component for lading with rotary loading cutter (Labrador 120) and loader (Cernin C11).

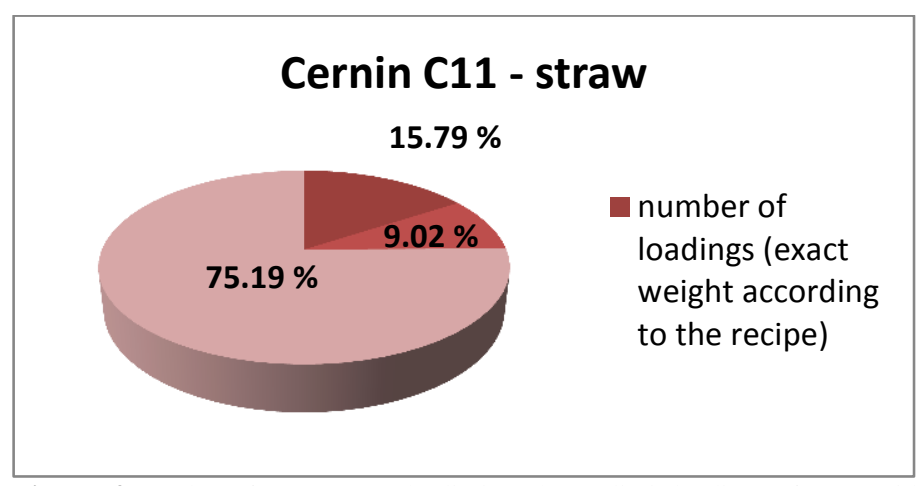

Figure 4 Number of accurate, under-limit and over-limit loadings of straw with loader

\section{Cernin C11 - haylage}

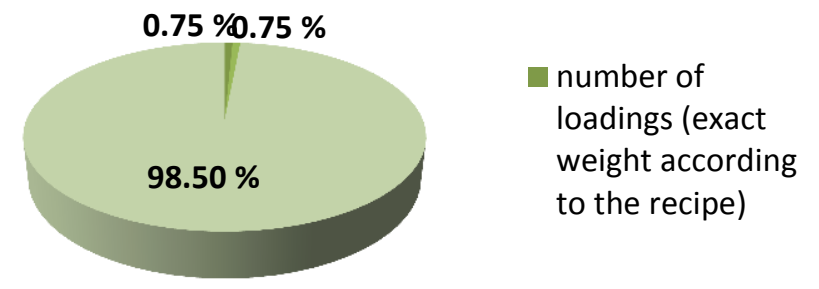

Figure 5 Number of accurate, under-limit and over-limit loadings of haylage with loader 


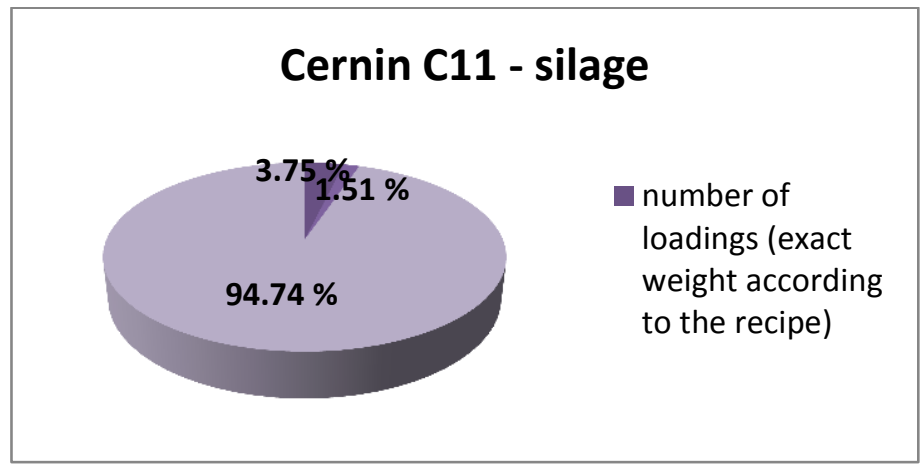

Figure 6 Number of accurate, under-limit and over-limit loadings of silage with loader

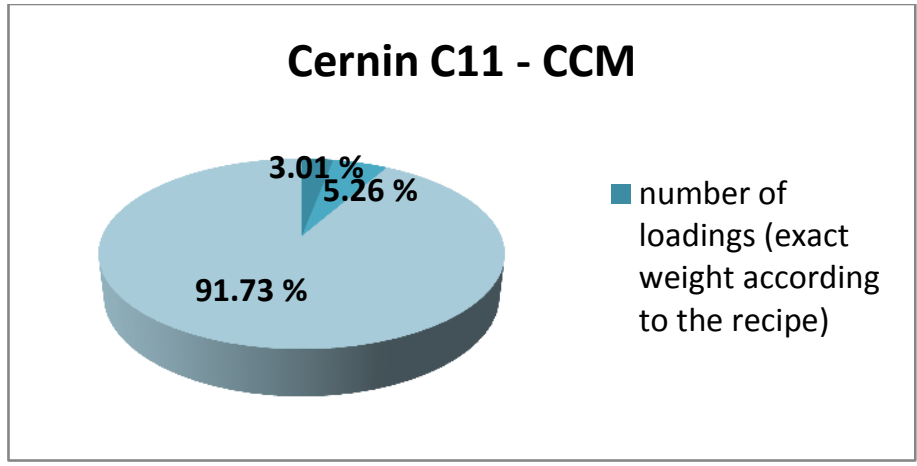

Figure 7 Number of accurate, under-limit and over-limit loadings of CCM with loader

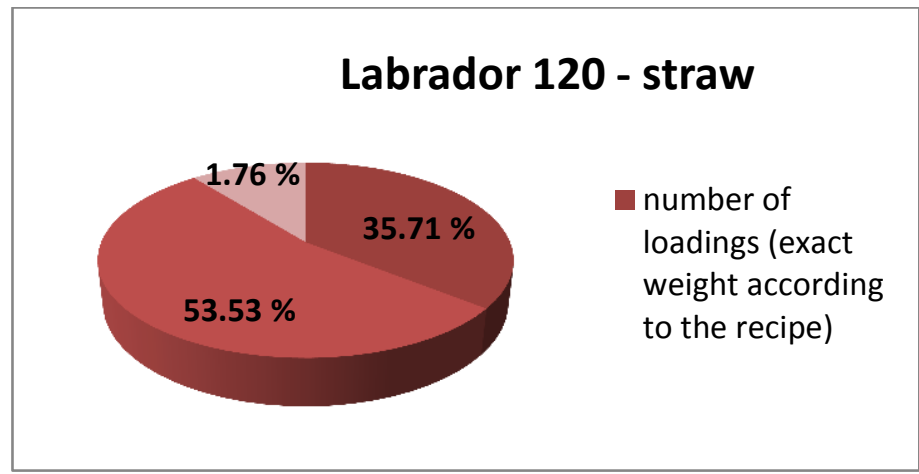

Figure 8 Number of accurate, under-limit and over-limit loadings of straw with loading cutter

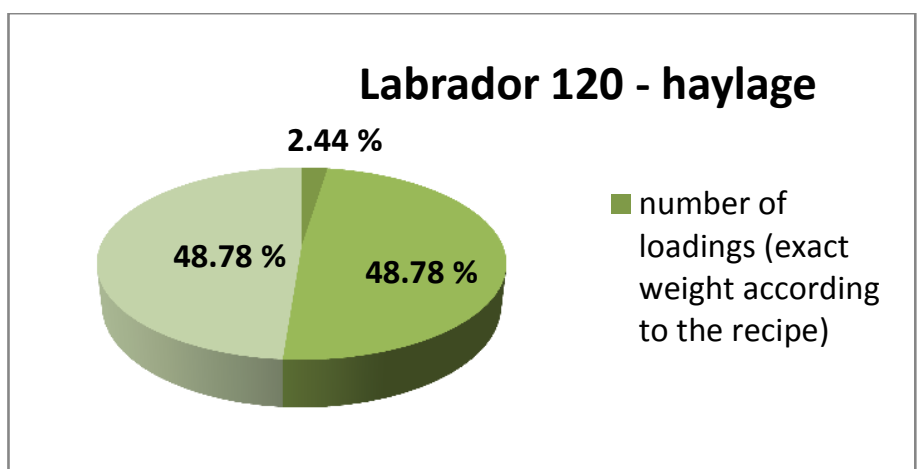

Figure 9 Number of accurate, under-limit and over-limit loadings of haylage with loading cutter

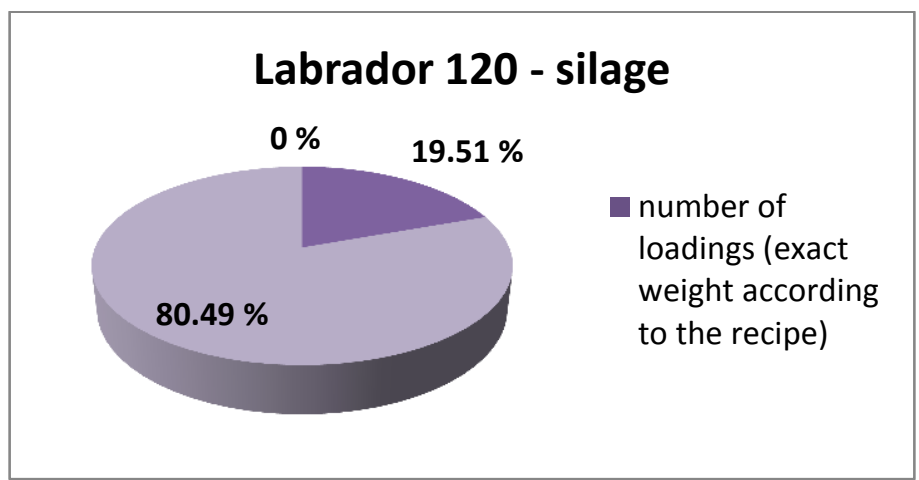

Figure 10 Number of accurate, under-limit and over-limit loadings of silage with loading cutter

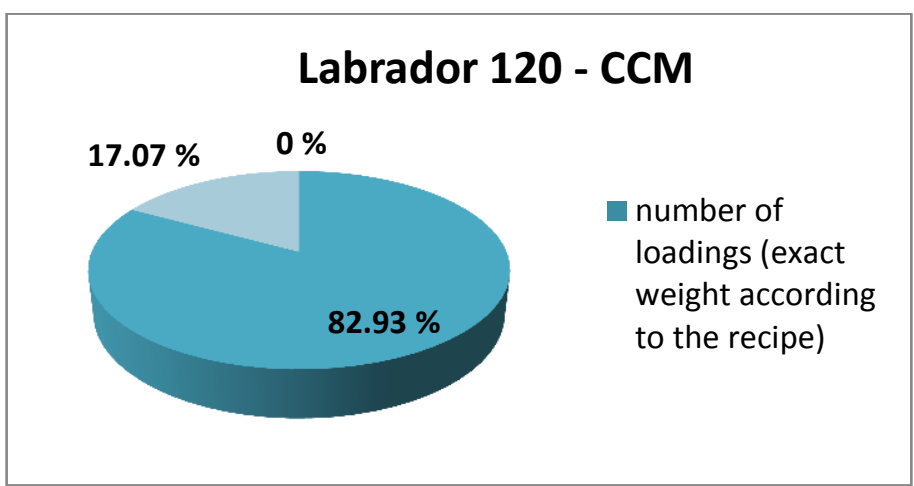

Figure 11 Number of accurate, under-limit and over-limit loadings of CCM with loading cutter

The highest number of exact loadings was found in straw in both methods of loadings (35.71\% cutter, $15.79 \%$ loader), shown in figure 12. The highest number of under-limit loadings was found in CCM (82.93\% cutter) and straw (9.02\% loader), shown in figure 13. The highest number of over-limit loadings was found in silage in both methods of loading (98.5\% loader, 80.49 cutter), shown in figure 14 .

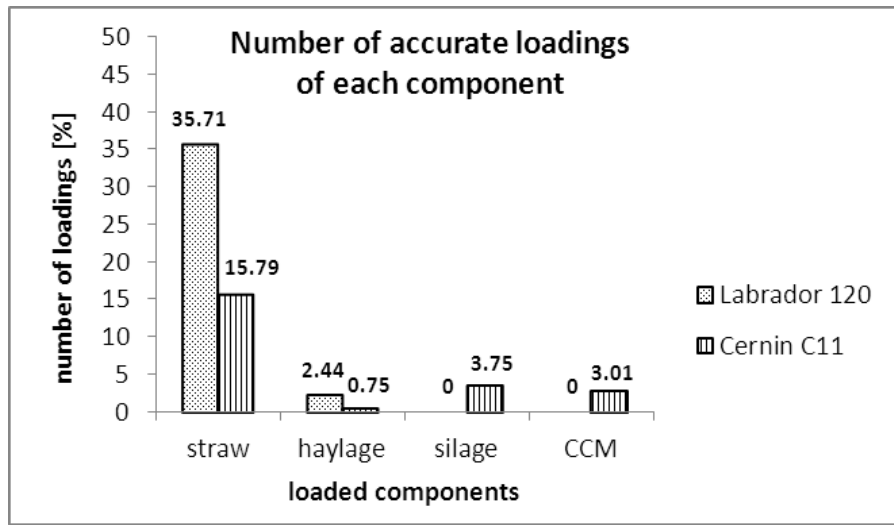

Figure 12 Number of accurate loadings of each component by loading with loading cutter (Labrador 120) and loader (Cernin C11)

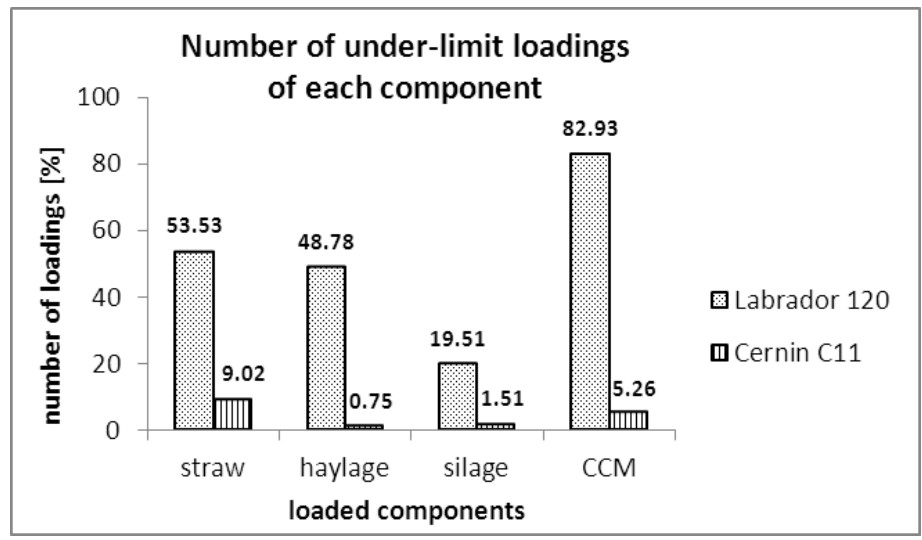

Figure 13 Number of under-limit loadings of each component by loading with loading cutter (Labrador 120) and loader (Cernin C11) 


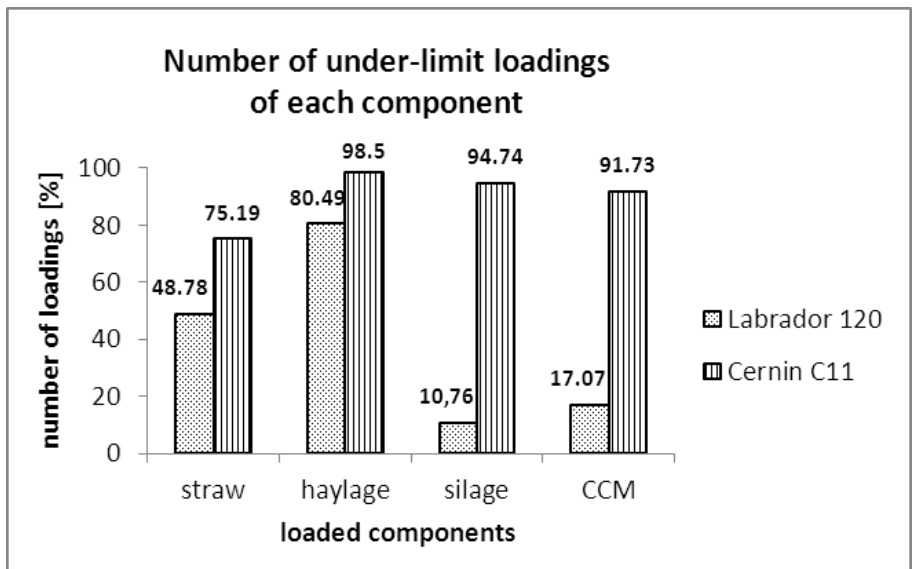

Figure 14 Number of over-limit loadings of each component by loading with loading cutter (Labrador 120) and loader (Cernin C11)

In figure 15 are shown average values of positive (over-limit) and negative (under-limit) deviations of the programmed (specified in the recipe) weights and standard deviations of the individual components by loading with loading cutter. When loading with loading cutter (Labrador 120) has been detected highest deviation in silage $(8.90 \%)$ and the smallest in the CCM $(2.93 \%)$. The highest under-limit deviation was found in CCM $(17.73 \%)$ and silage $(1.36 \%)$.

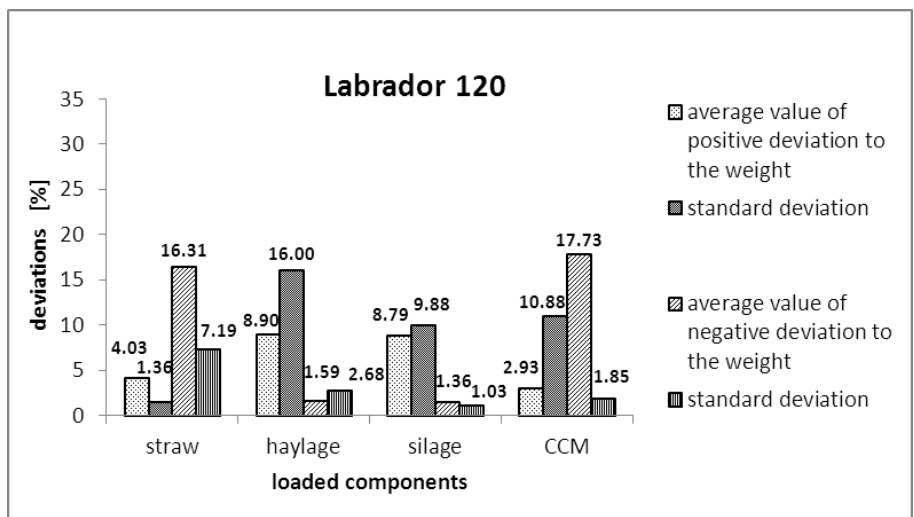

Figure 15 Average values of weight deviations and standard deviations by each component when loading with loading cutter (Labrador 120)

Figure 16 shows the average values of positive (over-limit) and negative (underlimit) deviations of the programmed (specified in the recipe) weights and standard deviations of individual components by loading with loader. In this method of loading has been found highest deviation of over-limit loadings in straw $(30.5 \%)$ and lowest in silage $(3.38 \%)$. The highest deviation of underlimit loadings was found in CCM (18.70\%) and lowest in silage $(1.33 \%)$.

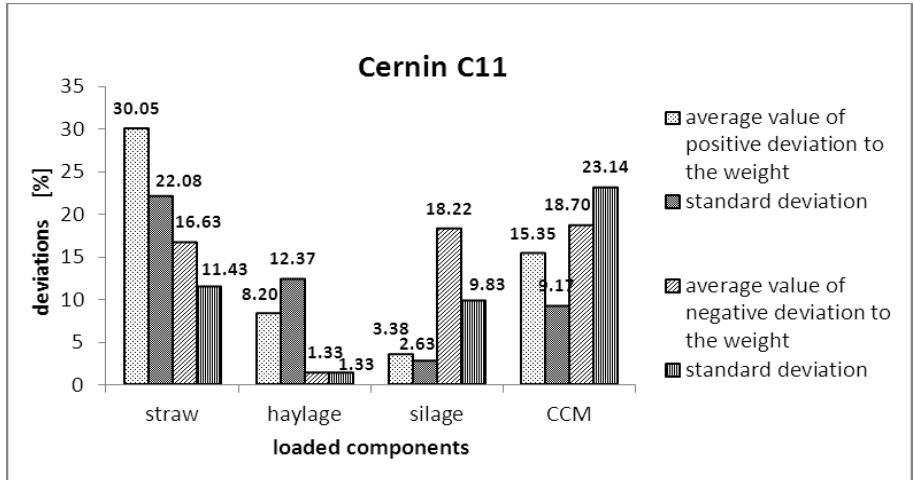

Figure 16 Average values of weight deviations and standard deviations by each component when loading with loader (Cernin C11)

In case of dry components with low cohesion (straw) was found the highest number of exact loadings. In case of wet components with higher cohesion (haylage), the number of exact loadings was low, in some (silage, CCM) there was no exact loading.

It can be noted that the highest number of exact loadings including all components was found in loadings with loading cutter. For each component was the highest precision of loading found in straw for each method. A higher number of under-limit loadings was found in loadings with loading cutter.
When loading with loader was found a high number of over-limit loadings for all components and also higher number of over-limit and under-limit standard deviations from prescribed weight for each component. Also, the unevenness of loadings is in this method considerably higher (shown in figure 15 and figure 16).

\section{CONCLUSION}

We can conclude, that the precision of loading of the individual components into the mixer feeder wagon depends not only on the method (used technique), but also on the kind, i.e. properties of loaded components. Dry components with low cohesion (straw) are loaded more accurately and components with lower humidity and greater cohesion (hay) are already loaded less accurately with a predominance of loadings above the limit for both types of loading.

For components with higher humidity (silage, CCM) is the number of accurate loadings low (loading with loader) or zero (loading by loading cutter). The number of over-limit loadings is high in loading with loader, in loading with loading cutter, prevalent in these components rather number of with under-limit loadings. Loading with loading cutter is considerably more even than with the loader.

\section{REFERENCES}

ALLEN, M. S. 2009. Grouping to Increase Milk Yield and Decrease Feed Costs. Tri-State Dairy Nutrition Conference, Michigan State University, April 21 and 22, 2009. s. 64

AMARAL-PHILLIPS, D. M., BICUDO, J. R., TURNER, L. W. 2002. Feeding Your Dairy Cows a Total Mixed Ration: Getting Started. Educational programs of the Kentucky Cooperative Extension Service. 2002

AMARAL-PHILLIPS, D. M., BICUDO, J. R., TURNER, L. W. 2010. Managing the Total Mixed Ration to Prevent Problems in Dairy Cows. Educational programs of the Kentucky Cooperative Extension Service. 2010

COPPOCK, C. E. et al., 1981. From feeding to feeding systems, J. Dairy Sci., 64 (1981), pp. 1230-1249. doi: http://dx.doi.org/10.3168/jds.s0022-0302(81)826987

DEVRIES T. J. et al., 2005. Frequency of feed delivery affects the behavior of lactating dairy cows. J. Dairy Sci., 88 (2005), pp. 3553-3562.doi: http://dx.doi.org/10.3168/jds.S0022-0302(05)73040-X

DEVRIES T. J., VON KEYSERLINGK M. A. G., 2005. Time of feed delivery affects the feeding and lying patterns of daiy cows. J. Dairy Sci., 88 (2005), pp. 625-631. doi: http://dx.doi.org/10.3168/jds.S0022-0302(05)72726-0

HOSSEINKHANI et al., 2008. The effects of feed bunk competition on the feed sorting behavior of close-up dry cows. J. Dairy Sci., 91 (2008), pp. 1115-1121. doi: http://dx.doi.org/10.3168/jds.2007-0679

JAVOREK, F. 2013. Technologie krmení a zastýlání. Mechanizace zemédělství. Ročník LXII, 2013(9), ISSN 0373-6776

JAVOREK, F. 2013. Provedení techniky pro př́pravu objemných krmiv. Mechanizace zemédělství. Ročník LXII, 2011(10), ISSN 0373-6776

JAMES, R. E., COX, B. 2008. Feeding Management to Reduce the Environmental Impact of Dairy Farms. Proceedings 45th Florida Dairy Production Conference, Gainesville, April 29, 2008. p. 40.

SINDHÖJ, E., RODHE, E. 2013. Manure handling techniques on case - study farms in Baltic Sea Region. Knowledge report, WP3 Innovative technologies for manure handling, Baltic Forum for Innovative Technologies for Sustainable Manure Management

STOKE, S. R. 1997. Particle Size and Ration Uniformity:Is it Important to the Cow? Western Canadian Dairy Seminar, 1997. (http://www.wcds.ca/proc/1997/ch20-97.htm)

SUCHÝ, P. et al. 2011. Výživa a dietetika II. díl. Výživa přežvýkavců Veterinární a farmaceutická univerzita Brno, 2011. s. 4 - 86. ISBN 978-80-7305599-8

VEGRICHT, J. et al. 2008. Inovace technických a technologických systémů pro chov dojnic. Metodická príručka MZe ČR. VÚZT Praha, 2008. s. 39-45. ISBN 978-80-86884-37-0

VEGRICHT, J., ŠIMON, J. 2012. Inovace v oblasti míchacích krmných vozů. Mechanizace zemědělství. Ročník LXII, 2012(11), ISSN 0373-6776 